\title{
Climate-growth Relationship of Pinus patula Schldl. et Cham. in Wondo Genet, South Central Ethiopia
}

\section{Belay TT* $^{*}$}

Department of Urban Environment and Climate Change Management, Ethiopian Civil Service University, Ethiopia

*Corresponding author: Belay TT, Department of Urban Environment and Climate Change Management, School of Graduate Studies, Ethiopian Civil Service University, Ethiopia, Tel: +251-9-13278801; E-mail: btiratu@yahoo.com

Received date: Oct 29, 2016; Accepted date: Nov 22, 2016; Published date: Nov 30, 2016

Copyright: @ 2016 Belay TT. This is an open-access article distributed under the terms of the Creative Commons Attribution License, which permits unrestricted use, distribution, and reproduction in any medium, provided the original author and source are credited.

\begin{abstract}
Most tropical regions are facing historical difficulties of generating biologically reconstructed long-term climate records. Dendrochronology (tree-ring studies) is a powerful tool to develop high-resolution and exactly dated proxies for climate reconstruction. In particular, dendroclimatological research is important in understanding both spatial and temporal characteristics of climate influences on tree growth. This project investigated the relationship between climate (precipitation and temperature) and tree rings, and showed its potential for climate reconstruction. Owing to the seasonal variation in rainfall, we expected the formation of annual growth rings in the wood of the forest of Wondo Genet. The project also carried out annual ring assessment and described the basic anatomical features of growth ring boundaries of the species under study. Wood disc samples of 15 trees belonging to the species of Pinus patula in the study site served to develop climate sensitive ring-width chronologies using standard dendrochronological techniques. A tree ring chronology was developed for the study species, and this enabled the assessment of the existing relationship between climate and tree growth patterns. The relationship between annual and seasonal precipitation, and mean monthly maximum and minimum temperature and ring-width indices was performed by correlation and simple regression analyses. The study species showed significant relationships with the rainy season precipitation proving the existence of annual tree rings $(r=0.42)$. Monthly correlation analysis also showed that rainfall during July had the highest positive and significant correlation with the growth of the study species $(r=0.50)$. The results indicated that annual growth of the species is primarily influenced by water availability during the growing (rainy) season. The study generally infers that the presence of anatomically distinct annual growth rings and high-quality cross dating and climate-growth relationships make the study species useful candidate for dendrochronological studies.
\end{abstract}

Keywords: Climate-growth relationship; Growth rings; Pinus patula; Wood anatomy

\section{Background and Justifications}

Climate change is of increasing concern to scientists because of its serious ramifications on ecosystems, in particular. Impacts from either global climate change or local climate variation can be imprinted on ecosystems [1]. To understand long-term impacts of climate change both in the past and in the future, it is necessary first to go beyond the time limit of instrumental records of climate. To this end, high resolution climate proxies are used to extend historical climate records back in time, providing a more comprehensive overview of trends in past climate $[2,3]$. Among these proxies that have the potential to express aspects of climate variability with perfect dating fidelity, at annual resolution, tree rings remain the most important and widely used sources of long-term proxy data [2].

Trees contain some of the nature's most accurate evidence of the past, because their growth largely depends upon local conditions such as temperature, water availability and phenology [4-6]. Tree-ring records are exceptionally valuable proxy for paleo-environmental study because of the following factors: They provide continuous records with annual to seasonal resolution; the existence of large geographic-scale patterns of synchronic inter-annual variability; the increasing availability of extensive networks of tree-ring chronologies; and the possibility of using simple linear models of climate-growth relationships that can be easily verified and calibrated [7].

Trees forming annual growth rings are found in many regions of the world. In temperate climates, trees add one ring yearly $[2,8,9]$. With the strong climate seasonality in temperate climates, growth-ring patterns are used as a climate proxy to reconstruct climate for the past $[8,10]$. In tropical areas, it has been widely assumed that trees do not form annual rings; but many researchers have succeeded in using tree rings in tropical trees to determine tree age, understand growth dynamics and carry out ecological and climate studies $[11,12]$. Indeed, tropical trees may have more than one growth ring formation per year depending on seasonality of growth [13]. In tropical climates with at least two arid months (bi-modal dry seasons), growth boundaries are usually visible, forming two rings per year [14].

The application of dendrochronology in tropical regions in general and Ethiopia in particular has been limited by the difficulty in finding trees with distinct annual rings that can be cross dated $[4,13,15]$. In Ethiopia, however, tree ring analysis using tree species, such as Juniperus procera from North Gondar [16], Acacia senegal, Acacia seyal, Acacia tortilis and Balanites aegyptiaca from the semi-arid savanna woodland [14]; Podocarpus falcatus, Pinus patula, Prunus africana and Celtis africana from the tropical mountain forest of Munessa-Shashemene [17]; Juniperus procera from Menagesh and Dodola [15,18]; Boswellia papyrifera from Lemlem Terara, Metema district, North-Western Ethiopia [19,20]; and Celtis africana from 
South Central Ethiopia [21] has been successful. Hence, one can suggest that the country has potential species and sites for dendrochronological studies.

Despite this, tree ring analysis using tropical tree species is still challenging owing to the reason that ring boundaries in such species are often less distinct than in species from temperate areas [12,22]. This is because seasonal changes in environmental conditions are often less pronounced in timing and intensity than in temperate areas $[22,23]$. This is manifested in anomalies like false rings, wedging rings, missing rings, and multiple rings formed per year [12-14,22]. To tackle these problems, knowledge of wood anatomy including investigation of growth rhythms and monitoring of cambial activity; testing the climate signal of additional tree-ring features; and comparison and later combination of chronologies from different species [12,22] are vital techniques.

The species selected for this study, $P$. patula, is believed to be economically important species which may be affected by the unfolding change in climate. So, understanding the climate variable which is significantly related to the growth dynamics of the study species will enable to generate reliable information for the sustainable management of these species. Besides this, the inevitability of climate change and the insufficiency of long-term instrumental climate data demand dendroclimatological research heading for an assessment of climate and tree growth relationship. In particular, in areas like Wondo Genet where few or no dendrochronological work has been made yet, the role that this study plays in filling the existing gap is unquestionable.

This study looked into wood anatomy and growth responses of $P$. patula to climate variability at different temporal scales using standard dendrochronological techniques in Wondo Genet, South Central Ethiopia. In this study, assessment of annual ring formation, description of wood anatomy of growth ring boundaries, and statistical analysis of climate-growth relationships were given due consideration.

\section{Objectives of the Study}

The specific objectives of this study are to describe wood anatomical features of the growth ring boundaries of the study species; verify whether the growth rings formed by the study species are annual or not; and determine the climate-growth relationship of the study species at different time scales.

\section{Materials and Methods}

\section{Description of the study area}

Wondo Genet is found in Sidama Zone of Southern Nations Nationality and Peoples Regional States. It is located $263 \mathrm{~km}$ southeast of Addis Ababa, and about $13 \mathrm{~km}$ from the nearest town Shashemene. It is located within the geographic coordinates of $7^{\circ} 06^{\prime} \mathrm{N}$ to $7^{\circ} 11^{\prime} \mathrm{N}$ latitude, and $38^{\circ} 05^{\prime} \mathrm{E}$ to $38^{\circ} 07^{\prime} \mathrm{E}$ longitude [25]. It occupies the Northeastern portion of Hawassa 'Zuria' district. Shashemene and Kofele districts of Oromia regional state border it in the Northern, North Western and North Eastern, and Eastern directions, respectively [26]. This study was carried out in Wondo Genet forest, found residing WGCF-NR, the major organization of the area where the major forest and the selected study species are found.

The topography of the Wondo Genet has mountains and hills covering $43.5 \%$, flat areas $36.25 \%$ and undulating parts $20.25 \%$ of the district $[24,25]$. The area comprises the hills of Abaro, Bachil Gigissa, Gariramo, Kentere and Cheko, and the depression surrounded by these hills. The height of land varies between 2,580 m a.s.l. at Abaro and $1,600 \mathrm{~m}$ a.s.l. around the marshy area. The higher altitudes and steep slopes support natural forest and lower altitudes and the gentle terrain consists mainly of farmlands. The forests found in Wondo Genet occupy most of the Northeastern parts of the area. The hillsides and their foot belong to most of these forests (Figure 1) [26,27].

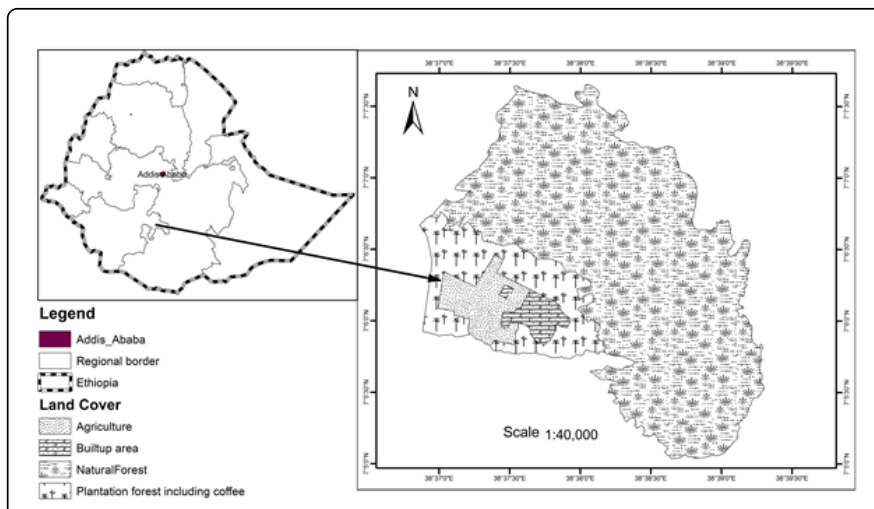

Figure 1: Location map of the study site.

The climate in Wondo Genet is characterized by two rainy seasons, a long rainy season from June to September and a short rainy season from March to May. The total annual rainfall range is between $800 \mathrm{~mm}$ to $1600 \mathrm{~mm}$. On the other hand, average annual temperature varies between $18^{\circ} \mathrm{C}$ and $21^{\circ} \mathrm{C}$. In most parts of Wondo Genet area, Woina dega (sub-tropical) agro-climatic type prevails (Figure 2).

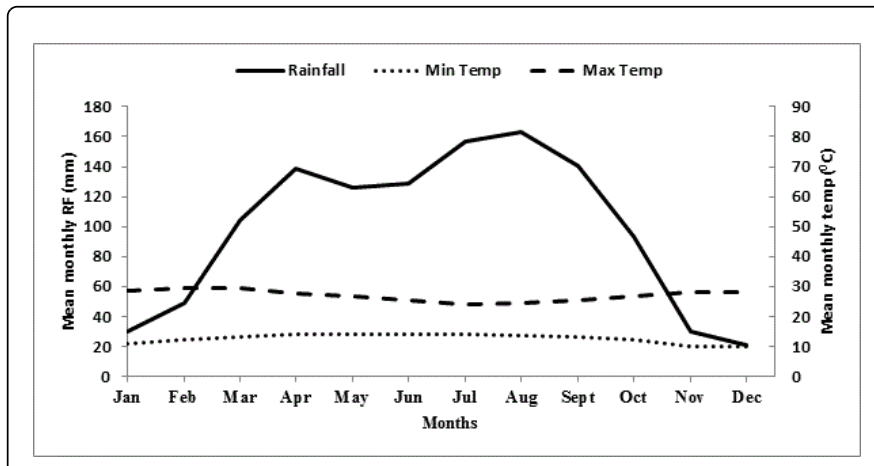

Figure 2: Climate diagram of the study area based on climate data obtained from the NMA of Ethiopia, Hawassa Branch Directorate and WGCF-NR (1983-2012).

\section{Sample collection}

A total of 15 stem discs were collected for the study species using a chainsaw. The samples of $P$. patula (10 stem discs) were collected at breast height $(\mathrm{DBH}, \sim 1.3 \mathrm{~m})$. The remaining samples of $P$. patula $(5$ stem discs) were collected at a height of $0.5-1 \mathrm{~m}$ above the ground [28], so that these samples could be used for verifying annual ring formation. Besides this, some additional tree cross sections were also removed from the branches of trees that had already been felled down for thin section preparation and anatomical studies. Moreover, in cases where the collected samples were checked problematic after the survey 
in the laboratory, for example, where detecting the growth bands were difficult due to the presence of dark heartwood, and/or where wedging, missing, locally absent and false rings were predominant, the discs were excluded from the sample and instead, additional stem disks were collected.

\section{Preparation of wood anatomy samples}

The basic anatomical features that depict the growth ring boundaries of the study species were examined by preparing microthin sections from the transverse planes of the samples using a sliding microtome [29,30]. Accordingly, some wood sections that fit the microtome (15 mm length and $2 \mathrm{~mm}$ width) were removed with a changing sampling point. Following this, thin sections of $30 \mu \mathrm{m}$ thickness were prepared with a sliding microtome (type G.S.L.1 light weight microtome). And then, the thin sections were stained with a mixture of Astra-blue and Safranin for 3-5 min to improve visibility/ contrast of the wood anatomical features of the study species. The stained thin sections were rinsed with de-mineralized water and dehydrated with a graded series of Ethanol (50\%, 96\% and 100\%). Then, for permanent fixation, the sections were rinsed with xylol and embedded in Canada-Balsam and dried at $60^{\circ} \mathrm{C}$ for $12 \mathrm{~h}$ in the oven [19]. Subsequently, the thin sections were photographed by a digital camera attached to a light microscope and desk top computer. Different images of a given sample were aligned automatically to a single image and then edited by correcting intensity of colour and focus with the help of Adobe Photoshop CS3 software. The terminology used follows the IAWA List of Microscopic Features for wood identification [31].

\section{Disc processing and ring width measurement}

After the discs were collected and transported to the wood-science laboratory of WGCF-NR, Ethiopia, they were air-dried for 2 weeks. Then, their cross-sectional surface was sanded using progressively finer grades of sandpapers $(60,80,120,220,320$ and 600 grits) ensuring maximum visibility of anatomical features. Cellular features of each disc were examined up to $40 \mathrm{X}$ magnifications using a stereoscopic microscope. If the bark was present, a calendar year was assigned for each ring by counting backwards from the most recent year's growth near the bark. If bark was missing, each ring was assigned a floating number, beginning with year one at the outermost ring.

Wood-anatomical features that depict growth-ring boundaries were studied on micro-thin sections $[29,30]$. Growth rings were detected by following concentric features around the stem circumference, and then identified when all rings on a disc and ring numbers and characteristics matched along different radii. Then, growth rings were marked and counted under stereo-microscope on four radial directions of the sample discs. Subsequently, the width of each growth ring was measured from the bark to the pith on each radius to compute a chronology. Tree-ring width was measured to the nearest $0.001 \mathrm{~mm}$ with a semi-automatic device, a LEICA MS 5 microscope coupled with LINTAB TM 5 digital measuring stage associated to TSAP-dos software, Rinn tech, Heidelberg, Germany [32].

\section{Cross-dating}

Cross-dating is a fundamental technique in dendrochronology, whereby distinctive series of narrow and wider tree rings are identified and matched among trees of different ages. In this study, the samples were cross-dated using a combination of visual and statistical techniques following the method of Stokes and Smiley [33]. The visual cross-dating involves documenting characteristic patterns of pointer years (extreme wide and narrow rings) and matching these patterns between samples [34]. Cross-dating allowed to checking and correcting for missing rings or false rings.

Furthermore, the similarity of individual curves were tested statistically with the computer program Time Series Analysis and Presentation (TSAP), which allowed the measurement of "Gleichlaufigkeitskoeffizient" (GLK) and t-values. These were the two statistical indicators used to evaluate the match between two time series. GLK indicates the percentage year-to-year harmony in the fluctuation of two curves within the overlapping period; and the tvalues convey the degree of similarity of two curves [8]. T-values and GLK were calculated within and between trees of each species to check whether the ring width measurements cross-date or not and to assess the quality of the final chronologies developed for climate-growth analysis. Consequently, a combination of $t$-values $\geq 4.0$ and a mean GLK $\geq 85.0(\mathrm{P}<0.001)$ were considered for further climate-growth analyses [20,35]. Samples that fail to cross-date through these stages were excluded from the subsequent analysis.

The statistical cross-dating was accomplished using COFECHA software [36]. For this, 32-year segments with 16-year overlaps in COFECHA were used to test the correlation between each series and the average of all other series. The critical threshold for such segment and overlap is $0.4093(\mathrm{P}<0.01)$ and $\mathrm{r}$-values above this were considered best for cross-dating and climate analysis, while segments below this value were flagged as potential cross-dating errors. Each disc, with flagged segments, was visually checked carefully under a microscope and re-measured when necessary.

\section{Standardization and chronology development}

Ring widths are not only affected by climate but also change with tree age, height within the stem, site-specific characteristics and site productivity $[2,12]$. For the study of climate-growth relationships, it is essential to determine the changes in ring widths associated with all other "noises" and remove them from the measurements. This correction is known as standardization, and the transformed values are referred to as ring-width indices [2,37]. The purpose of standardization is to remove an overall growth trend in tree-ring measurement series, and to remove part of the variance at very low frequencies approaching the length of the series [38].

All cross-dated measurement series were standardized to remove growth trends related to all other "noises" and minimize effects of autocorrelation in the time series [2,37]. The program ARSTAN was used to produce the standardized tree-ring index chronology [37]. Each tree-ring series was detrended (double detrending), employed based on the pattern of ring width measurements in TSAP) with a cubic smoothing spline of 32 years, which preserved $124.62 \%$ of mean series length to de-trend all series. This detrending curve was more flexible compared with some conservative methods, such as linear regression lines or negative exponential curves, and it removed the long-term non-climatic variations in growth [2]. With this procedure, it was possible to effectively eliminate age-related radial growth patterns so that ring-widths only reflect environmental constraints.

Three types of index chronologies were created using the program ARSTAN: standard, residual, and ARSTAN. To determine which chronology best suited to this study, a preliminary correlation analysis was conducted between climatic variables (temperature and 
precipitation) and each index chronology. All three index chronologies yield similar results implying that the interpretation of the influences of regional climate on tree growth was the same for all chronologies. The standard chronology, however, showed the highest correlation between tree growth and climatic variables and therefore was used in all further analyses. Then, tree ring indexed chronologies for the study species were constructed from the standard indexed chronology obtained from ARSTAN outputs.

\section{Climate data}

The climate-growth relationship for each of the study species was analyzed using monthly climate data (rainfall and maximum and minimum temperature) from 1983 to 2012 obtained from the National Meteorological Agency (NMA), Hawassa Branch Directorate. These data were, then, analyzed to gain reliable climate-growth related information. All climate-related information in this study was calculated from the data obtained from the agency. In some cases, climate data obtained from the NMA of Hawassa Branch Directorate were missing (not available), and hence data obtained from WGCF-NR Meteorological station (class I) daily observations for rainfall and temperature were used.

\section{Correlation and simple linear regression analyses}

Correlation and simple linear regression analyses were used to examine how regional climatic variables influence radial growth of the study species. Correlation analysis was used to describe associations between growth variability and climatic variability for the period 1983-2012. Pearson Product-Moment Correlation Coefficient (r) was calculated to describe associations between factor chronologies and monthly climatic variables. And, coefficient of determination from simple linear regression analyses (R2) was calculated to describe how well a regression line fits the set of data generated. The $\mathrm{R} 2$ attempted to look at the strength of relationships between the indexed ring widths and the climate variable in terms of deviations from the regression line or best-fit line.

Statistically significant coefficients indicated a confident association between a given climate variable in a particular month and tree growth. But more often, the climate effect on tree growth is stronger in the form of a multi-month seasonal signal [39]. In such cases i.e., when two or more consecutive months showed strong positive or negative correlations between growth and climate (temperature or precipitation), seasonal climatic variables were created and included in the correlation analysis. Seasonal variables (dry and rainy seasons) were formed by simple averaging of monthly climatic variables. Unless stated otherwise, all results are statistically significant at $\mathrm{P}<0.05$ i.e., at $95 \%$ confidence interval.

\section{Results}

\section{Description of wood anatomy of growth ring boundaries}

P. patula forms distinct growth rings. In some cases, wedging rings and false rings are also prevalent. It undergoes an abrupt transition from early wood to latewood boundaries. The early wood and late wood growth boundary is too visible to distinguish. Thus, tree ring formation is easier to study.

The microscopic cross section showed relatively simple wood anatomical structures. The axial or vertical system is composed mostly of axial tracheids and the radial or horizontal system is composed mostly of ray parenchyma cells (Figure 3). The latewood growth boundaries consist of narrow bands of radially flattened tracheids with slightly thickened cell walls. Intra-annual density variations and resin ducts are also common features of these species.

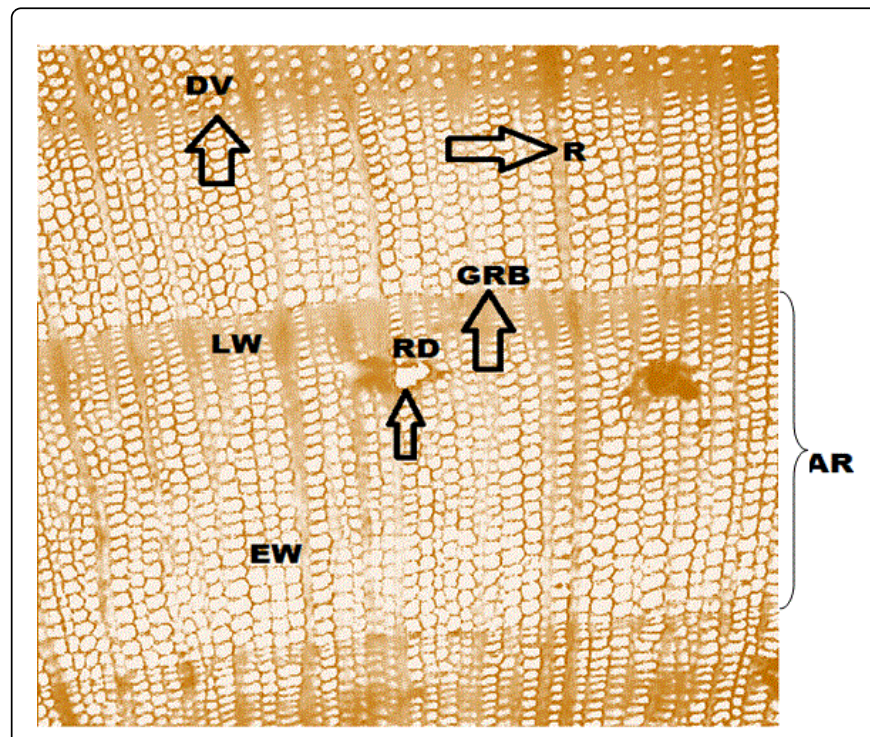

Figure 3: Transverse view of Pinus patula and its basic anatomical features (DV density variation, GRB growth ring boundary, AR annual ring, EW earlywood, LW latewood, $\mathrm{R}$ ray, and $\mathrm{RD}$ resin duct).

\section{Verification of annual ring formation, cross-dating and chronology development}

Samples of the studied species demonstrated that the distinct growth rings formed by the species are annual in nature. This was proved by ring counting in trees of known age. To this end, five sample discs that were cut between 0.5 and $1 \mathrm{~m}$ above ground level ensuring the visibility of maximum number of growth rings were used. The remaining ten discs were not used for annual ring assessment because they were cut at their $\mathrm{DBH}(1.3 \mathrm{~m})$ and hence do not ensure the visibility of maximum number of growth rings.

Information on the planting year and hence age of the samples was obtained from the final document of the Management Plan for Forest Plantations of WGCF-NR. Consequently, it was found out that ring counts of the five discs exactly coincided with the known age of the sampled tree species (Table 1 ). This readily proved the annual nature of tree rings. Here, it was considered that the seedlings had already grown to a height of 0.5-1 m before they were planted in the study site.

The other method used to assess the annual nature of rings was through climatological analysis of tree ring curves. In this regard, the statistical comparison between measured tree ring curves and climate data is helpful. Values of climatic variables of four months (June to September) assumed to be important for tree growth were seasonalized and compared to tree ring widths. 


\begin{tabular}{|l|l|l|l|l|}
\hline Sampled discs & $\begin{array}{l}\text { Comp. No. } \\
\text { (new) }\end{array}$ & Planting year & Age (years) & No. of rings \\
\hline Pin 1 & 45 & $1982 / 83$ & 30 & 30 \\
\hline Pin 2 & 53 & $1979 / 80$ & 33 & 33 \\
\hline Pin 3 & 53 & $1979 / 80$ & 33 & 33 \\
\hline Pin 4 & 45 & $1982 / 83$ & 30 & 30 \\
\hline Pin 13 & 49 & 1981 & 31 & 31 \\
\hline
\end{tabular}

Table 1: Comparison between number of rings and known age of the samples of Pinus patula. ${ }^{*}$ Rings were counted on the longest radii from the bark to the pith.

Choice of climate variables and periodic limits of the seasons were defined by the experience of the researcher. Accordingly, a more or less concurring shape of seasonal precipitation and tree ring curves that point to the formation of annual rings for the study species was found (Figure 4).

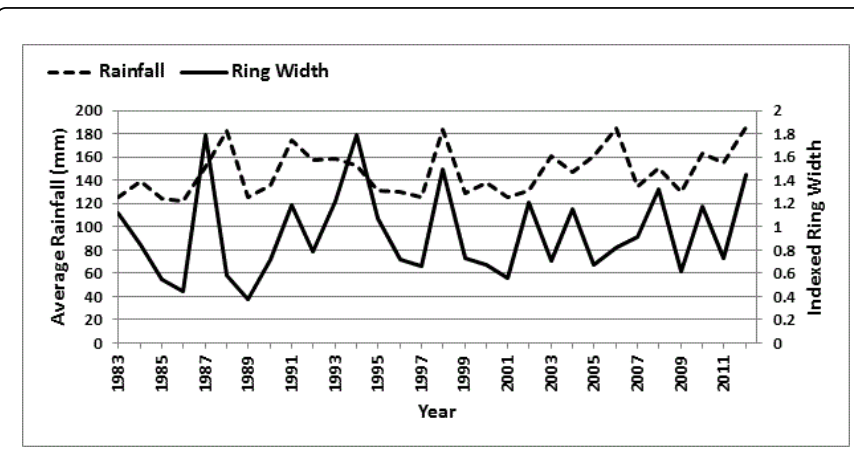

Figure 4: Illustration of the correlation between the ring-width index of Pinus patula and average seasonal rainfall (June to September) of 30-years interval from 1983 to $2012(\mathrm{P}<0.05)$.

Furthermore, cross-dating and the development of tree-ring chronologies for the study species were done successfully. Of the 15 stem discs that were collected for the study species, 14 of the sampled discs were cross-dated within and between trees (93.3\% success rate); while 1 discs could not be cross-dated, although these discs were later replaced by other samples and eventually cross-dated against the tree ring chronologies developed for the study species (Figure 5). As mentioned earlier, in this study, cross-dating of the study species was successful with a mean (GLK \%) range of $85-100 \%,(P<0.001)$ and tvalues $\geq 4$.

Out of the 60 measured tree ring series for each of the study species, 59 were retained for chronology building because of the accurate visual crossdating and COFECHA verification. The remaining series had correlation values less than the critical correlation level and hence they were removed before chronology development. The statistical crossdating quality of the discs was controlled by COFECHA outputs.

Accordingly, the mean correlations against the master chronology were 0.672 , which is greater than the critical correlation level of COFECHA, 0.4093 at $99 \%$ confidence interval (Table 2). This implies that the statistical crossdating for the species is highly significant.

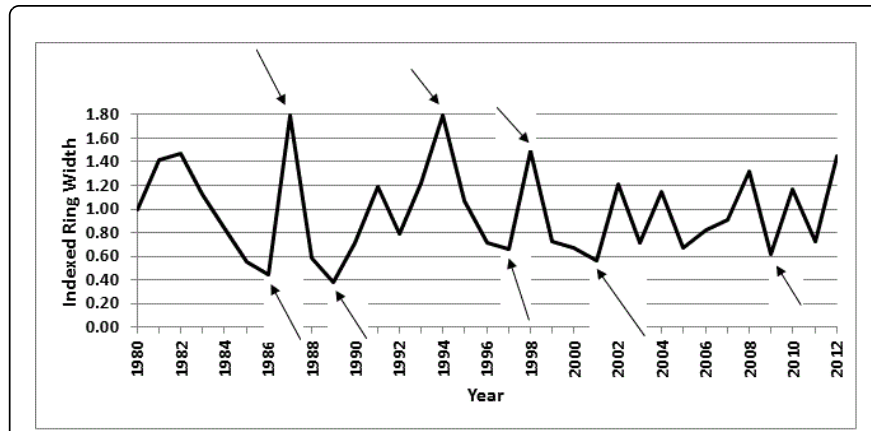

Figure 5: Tree-ring chronology developed for Pinus patula from 1980 to 2012 (Arrows indicate pointer years, extremely wide rings $(\searrow)$ and narrow rings $(\searrow)$.

\begin{tabular}{|l|l|}
\hline COFECHA output & P. patula \\
\hline Number of dated series & 59 \\
\hline Master series & 33 years (1980-2012) \\
\hline Correlation with master & 0.672 \\
\hline Average mean sensitivity & 0.537 \\
\hline Auto-correlation (unfiltered) & 0.6 \\
\hline No. of flags & 1 \\
\hline No. of segments & 67 \\
\hline
\end{tabular}

Table 2: Summarized COFECHA output of the study species.

\section{Climate-growth relationships}

Though variations exist in the degree of correlation between the species, correlation statistics showed that species' growth in the study site was positively correlated with the climate variables treated. The species showed highest and significant values of correlation coefficient (r) with precipitation amounts of the rainy season (June to September) (Table 3).

\begin{tabular}{|l|l|l|l|l|}
\hline \multirow{2}{*}{$\begin{array}{l}\text { Study } \\
\text { species }\end{array}$} & \multicolumn{4}{|l|}{ Correlation coefficient (r) value } \\
\cline { 2 - 5 } & Max. Temp & Min Temp & Annual RF & $\begin{array}{l}\text { Rainy } \\
\text { Season }\end{array}$ \\
\hline P. patula & 0.24 & 0.1 & 0.27 & $0.42^{*}$ \\
\hline
\end{tabular}

Table 3: Pearson correlation ( $r$ ) values between the radial growth chronology of the study species and different climate variables using a 30 -year common interval from 1983 to 2012 . ${ }^{*}$ High correlation during the rainy season.

The monthly correlation analysis resulted in both positive and negative relationships. The variables treated showed positive relationships during the months of January, August and September. Rainfall during the month of July had positive and significant correlation with the growth of the study species. Rainfall and minimum temperature during December had the highest negative relationships though the relationships were insignificant (Figure 6). 
Page 6 of 8

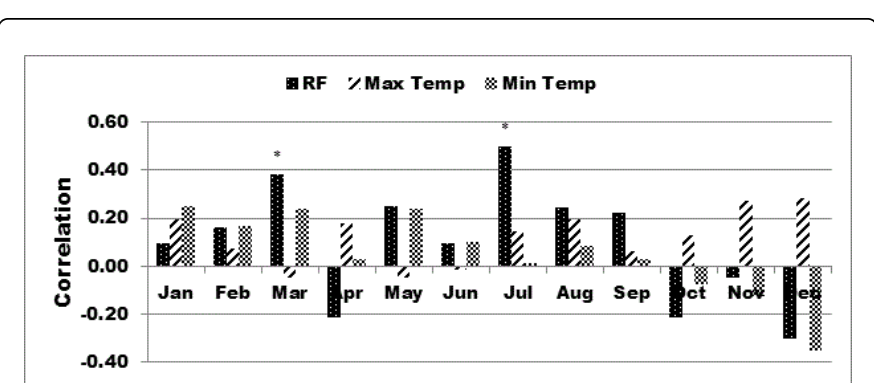

Figure 6: Correlations between indexed ring width of Pinus patula and average monthly climate variables $\left({ }^{*} \mathrm{P}<0.05\right)$.

Furthermore, simple linear regression analyses indicated significant positive relationships between annual radial increments and major rainfall season for the study species. This showed that the climate of the rainy season (summer rainfall) is very significant to the growth of the study species. With the remaining climate variables analyze, the study species showed statistically insignificant relationship.

Looking at the scatter plots, we find that the variance from the regression line explained by the major climatic variables varied substantially for the species. In this regard, the coefficient of determination (R2) allows us to explain the existing relationships in terms of variations from the regression or trend line. Accordingly, taking the highest R2 outputs, one can realize that $17 \%$ of the variations in the ring widths of $P$. patula are explained by the amount of rainfall during the major rainfall season. And, when we take the lowest R2, we observe that $1 \%$ of the variations in the ring widths $P$. patula are explained by the amount of mean monthly maximum and minimum temperature (Figure 7).

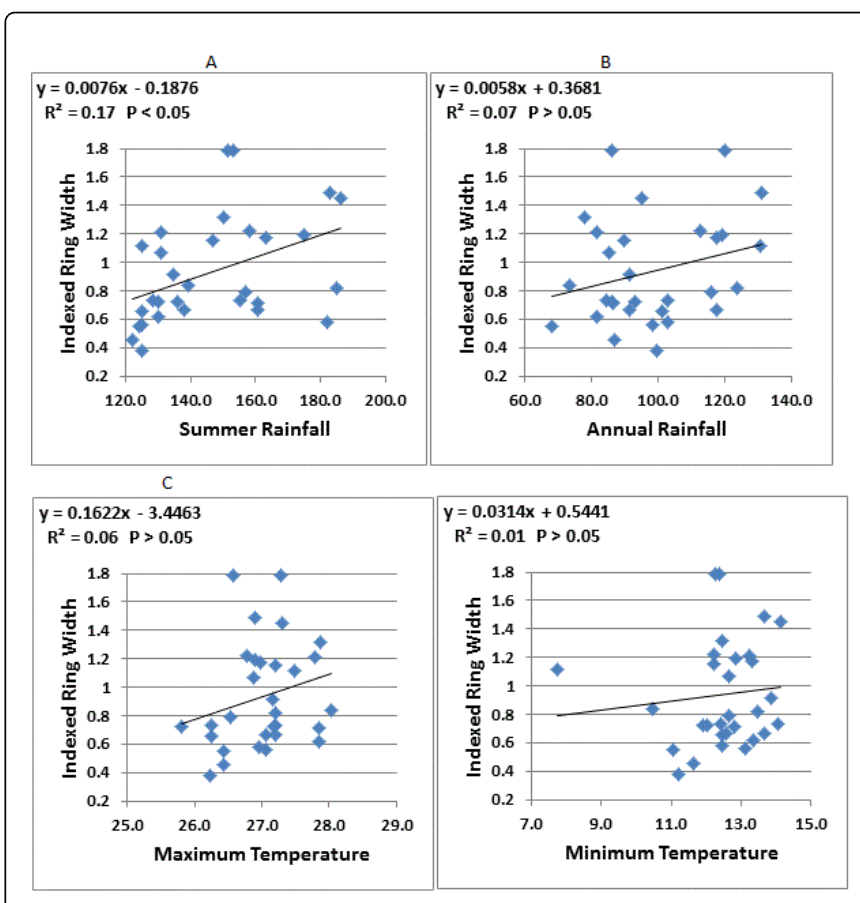

Figure 7: Simple linear regression between indexed ring widths of Pinus patula and the four climate variables analysed.
In general, both methods of analyses employed in this study (correlation and simple linear regression) resulted in similar outcomes in that they both showed high relationship between rainy season precipitation and radial growth of the species. In fact, the degree of relationship varied by variables treated.

\section{Discussion}

\section{Tree-ring formation and cambial activity}

The study species showed the formation of distinct rings. The variation in the distinctiveness of rings is mainly caused by differences in wood structure, which is species-specific [40]. For instance, the variations in the vessel size and distribution are a common feature in the wood structure of $P$. patula, as described for other tropical woods [31]. These wood anatomical features are indicators for periodic dormancy induced by seasonal precipitation patterns with a distinct dry season in tropical species $[11,41]$.

Ring width patterns of individuals from the same tree species at a study site have been successfully cross-dated. This indicates that there is an external oscillating factor triggering tree growth [42] which is the seasonal precipitation. This is shown by many other dendrochronological studies on tree species from tropical Africa and from the tropics world-wide $[14,30,40,42]$.

Although the study species form annual rings, crossdating was challenging. False rings and wedging rings occurred in the study species and are common problems in ring studies and in effective crossdating of tropical rainforest trees $[2,43,44]$. These irregular rings characters were successfully detected through differences in the anatomy of the ring and by checking the continuity of rings over the entire stem disc. False rings generally occurred just before the earlywood/latewood transition zone, suggesting that unusually low rainfall during earlywood growth might cause individuals to prematurely form tracheids with thicker cell walls, causing a false ring to appear before the formation of latewood cells. Wedging rings are believed to result from competition of species growing under poor light conditions [12].

The high incidence of such intra-annual growth zones and anomalous ring characters indicated the necessity to work with entire stem discs and makes the use of increment cores difficult $[30,17,42]$. Especially when working with new tropical species, as is the case in this study, it is absolutely necessary to start with entire stem discs for estimating dating accuracy and to learn anatomical differences between annual and non-annual growth zones. This was the main reason as to why this study preferred stem discs to increment cores, though it was ecologically destructive.

Growth periodicity in tropical areas is triggered when there is a dry season with less than $50 \mathrm{~mm}$ precipitation per month [11]. Decrease in precipitation at the beginning and during the dry season result in decreased soil water potential [14]. Species with different growth strategies respond differently to such climate events. At the most severe part of the dry period, when plant water potential reaches its permanent wilting point during the dry season, drought deciduous species shed their leaves and this is necessarily followed by a decrease in wood growth; and evergreen and deciduous species enter a period of cambial dormancy, which implies formation of growth boundaries. In agreement with this reasoning, both evergreen and deciduous species may show distinct growth rings. Our results also agree with previous 
studies, which showed that the study species form distinct annual growth rings $[11,14,44]$.

\section{Species' growth response to climate variability}

Correlation and simple linear regression analyses revealed significant relationships between radial growth and precipitation and indicated that annual growth of the species is primarily influenced by water availability during the growing (rainy) season. This corroborates with the findings of several authors who explained species' sensitivity to water availability in tropical areas [2,14,28,39]. Precipitation, somehow, determines the amount of moisture available in the soil. If there is high rainfall, the moisture available in the soil will get increased and this in turn initiates wood cambial activity and growth of species. In contrast, dry conditions will slow down soil moisture and this leads to cambial dormancy and hence new growth ceases until the next wet season [45-49]. In fact, the amount of soil moisture is also dependent on soil type.

In the study area, variation in growth in the study species is at least partly determined by rainfall as the relationship between growth and rainfall is generally positive. Studies showed that tree growth is influenced by rainfall in climates with comparable precipitation levels of $1000-1700 \mathrm{~mm}$. With a further rise in annual precipitation, however, it seems that growth is not limited by rainfall anymore, but by fluctuating patterns in photosynthetic radiation or air temperature $[31,50,51]$.

Monthly correlation analysis showed that available moisture during the early and late summer months is proved to be a vital factor of xylem (cell) production because these months make up the bulk of the growing season when trees need moisture the most. Moreover, rainfall during the beginning of dry season (November to December) had negative relationship with the growth of the species signifying the importance of long term moisture availability for proper growth. The relationship between radial growth and maximum temperature during the rainy season is higher implying that exotic species tend to prefer warmer climatic conditions for their growth. These findings are comparable with the findings of other dendroclimatological studies in tropical areas $[14,28,39]$.

Besides this, the statistical analyses between tree growth and climatic variables suggest that temperature has some degree of influence on the growth variation of the species under study. The response of tree growth to a change in temperature may differ in predictable ways. High latitude (temperate) tree growth may be temperature-limited and thus benefit from some degree of warming, as opposed to warm-adapted species $[1,6,52]$. In line with this reasoning, the study species reacted to temperature differently. That is, warmer temperature conditions had higher correlations with radial growth of $P$. patula. This implies that it benefited from high temperature amounts of the study site, as it is an exotic temperate species.

\section{Conclusion}

This study infers that the presence of anatomically distinct, annual growth rings, and high-quality cross dating, as shown by a high interseries correlation and statistically significant correlations with climate makes the study species useful candidate for dendrochronological studies in tropical regions in general and Ethiopia and the study site in particular. Despite this, however, the scope of this study is somehow limited owing to some factors like deficiency of long term and persistent meteorological data, and scarcity of time and finance. Thus, this study raises issues that merit further investigation.

\section{Acknowledgement}

Above all, I would like to present my thankfulness, with utmost sincerity, to the Almighty God for the wonderful privileges $\mathrm{He}$ bestowed up on me and my family. Next, I would like to express my gratitude to Erlangen University (Germany) for the provision of the research grant. I also thank Dr. Aster Gebrekirstos, Dr. Solomon Zewdie and Dr. Motuma Tolera for their consistent advice and followup from the beginning to the completion of this research. My deepest thanks also go to the National Meteorological Agency of Ethiopia, Hawassa Branch Directorate and Hawassa University, WGCF-NR.

\section{References}

1. Sass U, Killmann W, Eckstein D (1995) Wood formation in two species of Dipterocarpaceae in peninsular Malaysia. IAWA J 16: 371-384.

2. Fritts HC (1976) Tree Rings and Climate. Academic Press, London.

3. Cook ER (1995) Temperature histories from tree rings and corals. Clim Dynam 11: 211-222.

4. Verheyden A, Kairo JG, Beeckman H, Koedam N (2004) Growth rings, growth ring formation and age determination in the mangrove Rhizophora mucronata. Ann Botany 94: 59-66.

5. Bauch J, Quiros L, Noldt G, Schmidt P (2006) Study on the wood anatomy, annual wood increment and intra-annual growth dynamics of Podocarpusoleifolius var. macrostachyus from Costa Rica. Appl Botany Food Qual 80: 19-24.

6. Brauning A, Burchardt I (2006) Detection of growth dynamics in tree species of a tropical mountain rain forest in southern Ecuador. TRACE Tree Rings in Archaeology, Climatol Ecol 4: 127-131.

7. Hughes MK (2002) Dendrochronology in climatology-the state of the art. Dendrochronologia 20: 95-116.

8. Schweingruber FH (1988) Tree rings: basics and applications of dendrochronology. Kluwer Academic Publishers.

9. Briffa KR (2000) Annual climate variability in the Holocene: interpreting the message of ancient trees. Quatern Sci Rev 19: 87-105.

10. Smith D, Lewis D (2007) Dendrochronology. In: Encyclopaedia of Quaternary Science. Elsevier, Boston, pp: 459-465.

11. Worbes M (1999) Annual growth rings, rainfall dependent growth and long-term growth patterns of tropical trees from the Caparo Forest Reserve in Venezuela. Ecology 87: 391-403.

12. Worbes $M$ (2002) One hundred years of tree ring research in the tropics: a brief history and an outlook to future challenges. Dendrochronologia 20: 217-231.

13. Wils TH, Robertson I, Eshetu Z, Sass-Klaassen U, Koprowski M (2009) Periodicity of growth rings in Juniperus procera from Ethiopia inferred from crossdating and radiocarbon dating. Dendrochronologia 27: 45-58.

14. Gebrekirstos A, Mitlohner R, Teketay D, Worbes M (2008) Climategrowth relationships of the dominant tree species from semi-arid savanna woodland in Ethiopia. Trees-Structure and Function 22: 631-641.

15. Sass-Klaassen U, Couralet C, Sahle Y, Sterck FJ (2008) Juniper from Ethiopia contains a large-scale precipitation signal. Int J Plant Sci 169: 1057-1065.

16. Wils TH, Robertson I, Eshetu Z, Touchan R, Sass-Klaassen U, et al. (2010) Crossdating Juniperus procera from North Gondar, Ethiopia. Trees 25: 71-82.

17. Krepkowski J, Brauning A, Gebrekirstos A, Strobl S (2011) Cambial growth dynamics and climatic control of different tree life forms in tropical mountain forest in Ethiopia. Trees 25: 59-70.

18. Couralet C, Sass-Klaassen U, Sterck F, Bekele T, Zuidema PA (2005) Combining dendrochronology and matrix modelling in demographic 
studies: an evaluation for Juniperus procera in Ethiopia. Forest Ecol Manag 216: 317-330.

19. Tolera M, Menger D, Sass-Klaassen U, Sterck FJ, Copini P, et al. (2013) Resin secretory structures of Boswellia papyrifera and implications for frankincense yield. Annals of Botany 111: 61-68.

20. Tolera M, Sass-Klaassen U, Eshete A, Bongers F, Sterck FJ (2013) Frankincense tree recruitment failed over the past half century. Forest Ecol Manag 304: 65-72.

21. Hevia A, Sánchez-Salguero R, Linares JC, Olano JM, Camarero JJ, et al. (2016) Proceedings of the DENDROSYMPOSIUM 2015: May 20th-23rd, 2015 in Sevilla, Spain. German Research Centre for Geosciences 14: 74-77.

22. Wils THG, Sass-Klaassen UGW, Eshetu Z, Brauning A, Gebrekirstos A, et al. (2011) Dendrochronology in the dry tropics: the Ethiopian case. Trees 25: 345-354.

23. Cherubini P, Gartner BL, Tognetti R, Braker OU, Schoch W, et al. (2003) Identification, measurement and interpretation of tree rings in woody species from mediterranean climates. Biol Rev 78: 119-148.

24. Eshete G, Stahl G (1999) Tree rings as indicators of growth periodicity of acacias in the Rift Valley of Ethiopia. Forest Ecol Manag 116: 107-117.

25. Betru S (2006) Vegetation-environment interaction at small scale watershed: A study in Wondo Genet watershed vegetation. Environmental studies, Laboratory of Biosphere Information Sciences, Tokyo.

26. Gemechu T (2005) Prospects of Sustainable Natural Resource Management and Livelihood Development in Wondo Genet Area, Southern Ethiopia. MSc thesis, Addis Ababa University.

27. Kebede M, Kanninen M, Yirdaw E, Lemenih M (2012) Soil Seed Bank and Seedlings Bank Composition and Diversity of Wondo Genet Moist Afromontane Forest South Central Ethiopia. Botany 8: 170-180.

28. Couralet C (2010) Community dynamics, phenology and growth of tropical trees in the rain forest Reserve of Luki, Democratic Republic of Congo. Ghent University, Belgium.

29. Schweingruber FH, Borner A, Schulze ED (2007) Atlas of woody pant stems: evolution, structure and environmental modifications. SpringerVerlag, Berlin, p: 229.

30. Worbes M, Fichtler E (2010) Wood Anatomy and Tree-Ring Structure and Their Importance for Tropical Dendrochronology. In: junk WJ, Piedade MTF, Wittmann F, Schöngart J, Parolin P (eds.) Amazonian Floodplain Forests: Ecophysiology, Biodiversity and Sustainable Management. Ecological Studies 210: 329-346.

31. Worbes M (1989) Growth rings, increment and age of trees in inundation forests, savannas and a mountain forest in the Neo-tropics. IAWA J 10: 109-122.

32. Rinn F (2003) TSAP-Win, Software for tree-ring measurement analysis and presentation. Rinntech, Heidelberg, Germany.

33. Stokes MA (1996) An Introduction to Tree-Ring Dating. University of Arizona Press, Tucson, AZ.

34. Yamaguchi DK (1991) A simple method for cross-dating increment cores from living trees. Can J Forest Res 21: 414-416.

35. Enquist BJ, Leffler AJ (2001) Long-term tree ring chronologies from sympatric tropical dry-forest trees: individualistic responses to climatic variation. Tropical Ecol 17: 41-60.
36. Holmes RL (1983) Computer-assisted quality control in tree-ring dating and measurement. Tree-Ring Bulletin 43: 69-78.

37. Cook ER (1985) A time-series analysis approach to tree-ring standardization. University of Arizona.

38. Grissino-Mayer HD, Holmes RL, Fritts HC (1992) International tree-ring data bank program library: user's manual. Tucson: Laboratory of TreeRing Research, University of Arizona, p: 104.

39. Grissino-Mayer HD, Butler DR (1993) Effects of climate on growth of shortleaf pine (Pinus echinata Mill.) in northern Georgia: A dendroclimatic study. Southeastern Geographer 33: 65-81.

40. Brienen RJ, Zuidema PA (2005) Relating tree growth to rainfall in Bolivian rain forests: a test for six species using tree ring analysis. Oecologia 146: 1-12.

41. Schongart J, Orthmannw B, Hennenbergw KJ, Porembski S, Worbes M (2006) Climate-growth relationships of tropical tree species in West Africa and their potential for climate reconstruction. Global Change Biology 12: 1139-1150.

42. Worbes M (1995) How to measure growth dynamics in tropical trees-a review. IAWA J 16: 337-351.

43. Dunisch O, Bauch J, Gasparotto L (2002) Formation of increment zones and intraannual growth dynamics in the xylem of Swietenia macrophylla, Carapa guianensis, and Cedrela odorata (Meliaceae). IAWA J 23: 101-119.

44. Gebrekirstos A, Demel T, Masresha F, Mitlohner R (2006) Adaptation of five co-occurring tree and shrub species to water stress and its implication in restoration of degraded lands. Forest Ecol Manag 229: 259-267.

45. Powers RF (1981) Nutritional ecology of ponderosa pine (Pinus ponderosa Laws) and associated species. Ph.D. dissertation, University of California, Berkeley.

46. Carter GA, Miller JH, Davis DE, Patterson RM (1984) Effect of vegetative competition on the moisture and nutrient status of loblolly pine. Forest Resour 14: 1-9.

47. Oliver WW (1986) Growth of California red fir advance regeneration after over story removal and thinning. USDA Forest Resources Paper PSW, p: 180.

48. Byrne SV, Wentworth TR, Nusser SM (1987) A moisture strain index for loblolly pine. Forest Resour 17: 23-26.

49. Allen HL, Dougherty PM, Campbell RG (1990) Manipulation of water and nutrients-practice and opportunity in southern U.S. pine forests. Forest Ecol Manag 30: 437-453.

50. Clark DA (1994) Climate-induced annual variation in canopy tree growth in a Costa-Rican tropical rain-forest. Ecology 82: 865-872.

51. Stahle DW, Mushove PT, Cleaveland MK, Roig FA, Haynes GA (1999) Management implications of annual growth rings in Pterocarpus angolensis from Zimbabwe. Forest Ecol Manag 124: 217-229.

52. Way DA, Oren R (2010) Differential responses to changes in growth temperature between trees from different functional groups and biomes: a review and synthesis of data. Tree Physiol 30: 669-688. 